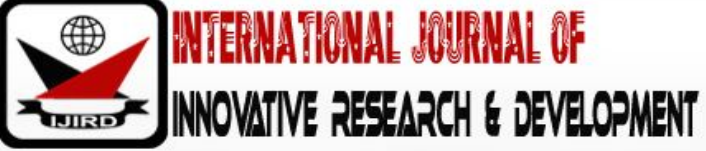

ISSN 2278 - 0211 (Online)

\section{Influence of Rhizobium Inoculation on Nodulation, Biomass Production and Yield of Some Indigenous Legumes in the Rainforest Agro-Ecological Zone of Nigeria}

\begin{tabular}{c}
\hline T. O. Ojikpong \\
Lecturer, Department of Agronomy, Cross River University of Technology, Obubra Campus, Nigeria \\
W. B. Binang \\
Lecturer, Department of Crop Science, University of Calabar, Nigeria \\
F. O. Takim \\
Lecturer, Department of Agronomy, University of Ilorin, Nigeria
\end{tabular}

\begin{abstract}
:
A field study was conducted during the late cropping seasons of 2015 and 2016 at Akamkpa (latitude $5^{\circ} 15^{\prime} \mathrm{N}$ and longitude $8^{\circ} 22^{\prime} E$ ), southern Nigeria, to evaluate the response of some legume genotypes to seed inoculation with NoduMax, a Rhizobium inoculant developed by the International Institute of Tropical Agriculture (IITA).

Treatments were factorial combinations of inoculated and non-inoculated seeds of Cowpea, Groundnut, Bambara groundnut, Bebi (Viny Lima) bean, Mucuna bean, and African yam bean, laid out in randomized complete block design replicated thrice. The response of the test crops to inoculation varied with growth stage. At the seedling stage, effective nodule number was not significantly affected in all but Mucuna bean in which there was a $42.7 \%$ reduction. At pre-an thesis, Bambara groundnut, Bebi bean, Groundnut, and Cowpea recorded a statistically similar number of nodules $(\mathrm{p}=0.05)$ under inoculated and noninoculated conditions, but inoculation reduced nodule formation in Mucuna bean and African yam bean by 22.4 and 20.4\%, respectively. Nodule dry weight of Bebi bean, Bambara groundnut, Mucuna bean and Cowpea was unaffected by inoculation when assessed at the seedling and pre-anthesis growth stages, but that of Groundnut was reduced by 35, and African yam bean increased by $60 \%$, respectively. Inoculation increased the nodule dry weight of African yam bean and Mucuna bean by 56.5 and $60.6 \%$ at seed initiation stage, and reduced that of Bambara groundnut and Groundnut by 25.6 and 50.0\%, respectively. The effect of genotype $\times$ inoculation interaction on plant biomass and fresh grain yield was significant; whereas inoculation significantly increased the yield of Cowpea from 2,471 to 2,794 kg/ ha and 2,995 to $3504 \mathrm{~kg} / \mathrm{ha}$ in 2015 and 2016, respectively, it did not significantly affect that of Bebi bean, African yam bean and Bambara groundnut. On the contrary, the yield of groundnut was reduced from 884 to $560 \mathrm{~kg} / \mathrm{ha}$ and 963 to $678 \mathrm{~kg} / \mathrm{ha}$ in 2015 and 2016, respectively. Inoculation with NoduMax was beneficial to cowpea, but did not significantly improve the performance of Bebi bean, and Groundnut. It could be that Bebi bean is promiscuous and better adapted to the native strains of Rhizobium, while the Rhizobium in Groundnut is antagonistic and incompatible with the introduced inoculants. Binang et al.; JALSI, 11(4): 1-9, 2017; Articleno.JALSI.32624 2 recorded a statistically similar number of nodules $(\mathrm{p}=0.05)$ under inoculated and non-inoculated conditions, but inoculation reduced nodule formation in Mucuna bean and African yam bean by 22.4 and 20.4\%, respectively. Nodule dry weight of Bebi bean, Bambara groundnut, Mucuna bean and Cowpea was unaffected by inoculation when assessed at the seedling and pre-anthesis growth stages, but that of Groundnut was reduced by 35, and African yam bean increased by $60 \%$, respectively. Inoculation increased the nodule dry weight of African yam bean and Mucuna bean by 56.5 and $60.6 \%$ at seed initiation stage, and reduced that of Bambara groundnut and Groundnut by 25.6 and $50.0 \%$, respectively. The effect of genotype $\times$ inoculation interaction on plant biomass and fresh grain yield was significant; whereas inoculation significantly increased the yield of Cowpea from 2,471 to 2,794 kg/ha and 2,995 to $3504 \mathrm{~kg} / \mathrm{ha}$ in 2015 and 2016, respectively, it did not significantly affect that of Bebi bean, African yam bean and Bambara groundnut. On the contrary, the yield of groundnut was reduced from 884 to $560 \mathrm{~kg} / \mathrm{ha}$ and 963 to $678 \mathrm{~kg} / \mathrm{ha}$ in 2015 and 2016, respectively. Inoculation with NoduMax was beneficial to cowpea, but did not significantly improve the performance of Bebi bean, and Groundnut. It could be that Bebi bean is promiscuous and better adapted to the native strains of Rhizobium, while the Rhizobium in Groundnut is antagonistic and incompatible with the introduced inoculants.
\end{abstract}

Keywords: Rainforest zone, legume, nodu max inoculants, native rhizobia, root nodule.

\section{Introduction}

Legumes are a valuable source of plant protein and constitute the major source of dietary protein for the poor in most parts of sub-Saharan Africa. The residues as well as herbaceous and fodder tree legumes provide an excellent source of quality feed for livestock [1], while their ability to fix atmospheric nitrogen (N2) makes them desirable components of 
farming systems, as they provide residual nitrogen and reduce the need for mineral fertilizers by associated non-legumes [2,3]. According to [4], the soil incorporation of legume residues can give a net nitrogen accrual of $140 \mathrm{~kg} \mathrm{~N} / \mathrm{ha}$, depending on the species of the legume. The conversion of atmospheric N2 to ammonium ions is a symbiotic process in which plant roots are infected by a bacterium (Rhizobia), which penetrates the root hairs to induce the formation of nodules, the seat of symbiotic fixation [5]. Several factors affect symbiotic nitrogen fixation in legumes [6]. Host plant interactions with Rhizobia determine which strains infect the root, the extent of nodulation, timing of its onset, and the potential of nitrogen fixation, while differences in nitrogenase activity, nodule number, nodule weight and plant top weight in response to given rhizobial strains have been identified [7]. Under adverse conditions, as found in many soils, symbiosis is not effective and biological nitrogen fixation is inhibited. Such conditions include absence of compatible rhizobial strain, inadequate amount of native rhizobia in terms of number, or ineffective or less effective native rhizobia relative to the intended legume [8,9] and [10]. This may be overcome by either the use of 'promiscuous' varieties which are non-specific with respect to rhizobial strains [5], or inoculating seeds with the desired bacteria [11]. Although the use of rhizobial inoculants is a wellestablishedpractice in the more developed countries, it is not widespread in sub-Saharan Africa, because it is often less successful in the tropics. According to [12], inadequate demonstration of the technology, presence of adequate native rhizobia, high soil mineral nitrogen level, inadequate quality control of Rhizobiuminocula and difficulty in inoculation under tropical conditions are some of the reasons for the poor response of rhizobial seed inoculation in sub-Saharan Africa. This situation is however, expected to change with the introduction of NoduMax, a commercial Rhizobium inoculant developed by the International Institute of Tropical Agriculture (IITA) for soils in the region [13]. Effective nodulation and nitrogen fixation may also be constrained by an unfavourable environment for both the host plant and its micro symbiont. In this regard, the major limiting factors are drought [14], level of soil nitrate [15,16], and intercropping [17,18]. However, effective legume/ Rhizobiasymbiosis can result in the fixation of more than $150 \mathrm{~kg} \mathrm{~N} /$ ha, and supply 80 to $90 \%$ of the host plant's nitrogen requirement [15]. Documentary evidence on the inclusion of grain and forage legumes in the mixed farming systems of northern Nigeria which is mainly semiarid and savannah abound [1,19], but information on their use, as well as the use of the many indigenous 'underexploited' leguminous species that are abundant in many parts of the country is scanty. The objective of this study was to evaluate the response of African yam bean, Bebi bean, Bambara groundnut, Cowpea, groundnut and Mucuna bean to inoculation with NoduMax, a local Rhizobium inoculant in a rainforest zone of south southern Nigeria.

\section{Materials and Methods}

\subsection{Description of Study Site}

A field experiment was conducted in 2015 and 2016 at Awi (latitude 5o15' $\mathrm{N}$ and longitude 8o22'E) in Akamkpa Local Government Area of Cross River State. The site experiences a bi-modal annual rainfall of between $2800-3200 \mathrm{~mm}$, with peaks in July and September and a dry spell in August; a minimum and maximum ambient temperature of 22 and $31^{\circ} \mathrm{C}$, respectively and a relative humidity of $80-89 \%$. Based on the USDA soil taxonomy, soils in the area are Ultisols containing low amounts of total nitrogen, but with a high $\mathrm{C} / \mathrm{N}$ ratio. Basic cations such as $\mathrm{Ca}, \mathrm{Mg}$ and $\mathrm{K}$ are easily leached leaving mostly Al3tand $\mathrm{H}$ +ions on the adsorption complexes. As a result of their inherently averse physical condition, high porosity, low nutrient reserve and low $\mathrm{pH}$, the soil requires special management practices for sustainable crop production, such as the planting of acid-tolerant crop varieties and liming [20].

\subsection{Treatments and Experimental Design}

A piece of farmland measuring $75 \mathrm{~m} \mathrm{x} 16 \mathrm{~m}(1,200 \mathrm{~m} 2)$ was manually prepared and demarcated into three blocks each with twelve (12) experimental plots of $5.0 \mathrm{~m} \times 5.0 \mathrm{~m}$. Blocks were separated from each other by a $2.0 \mathrm{~m}$ - wide path, and experimental units by a boundary of $1.0 \mathrm{~m}$. The land was flat-tilled, but $15 \mathrm{~cm}$ high mounds were raised for planting African yam bean. Treatments were factorial combinations of inoculated and non-inoculated leguminous species laid out in randomized complete block design replicated thrice. The test legumes were Cowpea (Vigna unguiculata L. Walp.; var. IT 98K-131-2), Groundnut \{Arachis hypogeaL. var. SAMNUT 24 (ICAR 19 BT)\}, Bambara groundnut (Vignasubterranea (L)Verdc.), Bebi (Viny Lima) bean \{Phaseolus lunatusL. (syn. P. limensisMacf.; P. inamoenusL.)\}, Mucuna bean (Mucuna pruriens var. utilis), and African yam bean \{Sphenostylis stenocarpa(Hochst Ex A. Rich.) Harms.\}. SAMNUT 24 is an earlymaturing groundnut variety that was released in 2011. It is resistant to several biotic stresses including Groundnut rosette disease. IT $98 \mathrm{~K}-131-2$ is a semi-determinate, early-maturing cowpea variety released in 1998, while landraces of African yam bean, Bebi bean, Bambara groundnut and Mucuna bean used in the study had indeterminate growth habits. NoduMax was applied at the rate of $100 \mathrm{~g} /$ ha following the procedure of [21]. Four seeds of each legume were sown per hole and seedlings thinned to two per stand, two weeks after sowing (WAS). Cowpea, Bambara groundnut, and Groundnut were sown at a spacing of $45 \mathrm{~cm} \times 45 \mathrm{~cm}$, while spacing for African yam bean, Bebi bean, and Mucuna bean was $90 \times 90 \mathrm{~cm} .20$ $\mathrm{kg} / \mathrm{ha} \mathrm{N}, 60 \mathrm{~kg} / \mathrm{ha} \mathrm{P} 2 \mathrm{O}$, and 40kg/ ha K2O were worked into the soil per treatment, one week before planting, and Indian bamboo was used to stake both African yam bean and Bebi beans at 6 WAS, while manual weeding was carried out at 4 and 8 WAS. Prior to field establishment in 2015 and 2016, soil samples were randomly collected using soil auger from a depth of 0-30 cm. The samples were bulked to form a composite sample and sub-samples collected, air-dried, sieved with a $2 \mathrm{~mm}$ mesh and analyzed for physical and chemical properties using procedures of [22]. At 4, 6 and 8 WAS, the number of effective root nodules per plant and nodule dry weight was evaluated based on 10 randomly selected plants, using the method of [23]. The sampling periods of 4, 6, and 8 WAS corresponded to the seedling, pre-anthesis and seed initiation stages of plant growth. The soil around the tagged plants was moistened with water the evening before six samples were collected in each plot using a shovel to excavate to a depth of $0.20 \mathrm{~m}$. In the laboratory, nodules were removed from the 
roots, washed with water, counted and dried in a forced-air oven to constant weight. A nodule was considered effective if its internal tissue was pinkish-red [5]. The number of pods per plant, number of seeds per pod, weight of 100 seeds, grain yield and plant biomass were assessed at physiological maturity. Shoot samples from 10 randomly selected plants per plot were oven-dried to constant weight at $80^{\circ} \mathrm{C}$, ground and digested with nitric-perchloric acid mixture, and analyzed for total N using the Salicyclic acid modification of the semi-micro Kjeldhal method, and total carbon concentration using a total carbon analyzer. Data collected were analyzed using the SAS software version 8 [24], and mean comparison was by Duncan's Multiple Range Test (DMRT) at 5\% probability level.

\section{Results and Discussion}

\subsection{Physical and Chemical Properties of the Soil}

The result of soil analysis presented in Table 1 show that the soil was acid sandy loam containing high amounts of organic carbon and available phosphorus, but was low in total nitrogen and effective cation exchange capacity (ECEC) (Table 1). The high sand fraction of the soil may be attributed to the nature of their parent material, and its low $\mathrm{pH}$ and ECEC to excessive rainfall that caused the leaching of basic cations beyond the rooting zone, leaving behind the acidforming $\mathrm{H}+$ and Al3+ions. The organic carbon content of the soil was low, similar to reports by [25] while the high base saturation indicates that it may be suitable for the cultivation of arable crops if measures are taken to alleviate soil acidity.

\begin{tabular}{|c|c|}
\hline Soil Property & Test Value \\
\hline Ph & 5.2 \\
Organic carbon (\%) & 2.10 \\
Total nitrogen (\%) & 0.11 \\
Available phosphorus (mg/ kg) & 16.0 \\
Exchangeable bases (cmol/kg): & \\
Ca & 4.4 \\
Mg & 2.0 \\
Na & 0.08 \\
K & 0.19 \\
Al3+ + (cmol/ kg): & 0.31 \\
H+ & 0.56 \\
ECEC (cmol/ Kg) & 8.9 \\
Base saturation (\%) & 78.0 \\
Particle size (\%) & 78.3 \\
Sand & 15.0 \\
Silt & 6.70 \\
Clay & Sandy loam \\
Texture & \\
\hline
\end{tabular}

Table 1: Pre-Planting Physical and Chemical Properties of Soil at the Study Site

\subsection{Nodulation Characteristics of the Legumes}

In terms of number of effective root nodules produced per plant, inoculating seeds with NoduMax was not beneficial to the genotypes evaluated when sampled at the seedling stage (Table 2), but rather depressed nodulation in Mucuna bean by $427 \%$. At the pre-anthesis growth stage, the number of effective nodules produced by Bambara groundnut, Bebi bean, Groundnut, and Cowpea were statistically similar under inoculated and non-inoculated conditions, but inoculation depressed nodule formation in Mucuna bean and African yam bean by 22.4 an $20.4 \%$, respectively.

At seed initiation stage however, the difference between the various genotypes with respect to effective nodule numbers was not significant, implying that formation of nodules at this stage of growth is dependent on the plant's genotype. Inoculated Cowpea consistently outperformed the non-inoculate Cowpea in terms of the production of effective root nodules. At 4, 6, and 8 WAP, inoculated Cowpea produced an average of 18.0, 20.7 and 18.7 effective nodules per plant, compared with 13.0,15.7, and 13.8, respectively produced by the non-inoculated plants. In general, the highest number of nodules was borne by Bambara groundnut, followed by Bebi bean, African yam bean, Mucuna bean, Cowpea and Groundnut, respectively. Cowpea and Groundnut both of which had a determinate growth pattern attained maximum nodulation two weeks earlier than other test crops, implying that peak biological nitrogen fixation occurs early in their life cycle. Studies of [26] similarly found that in Cowpea, nodule number and weight is higher at early stages of ontogeny. It would therefore, be preferable to deploy such genotypes as relay crops in which case either of them would be planted 4-5 weeks before introducing a medium-duration, non-legume relay crop that would benefit from the nitrogen they fix. Consequently, crop varieties selected for inclusion in this cropping option should be of early-medium duration, and drought tolerant since they would be expected to mature during the dry season. For this scheme to be successful, it may necessary to develop viable pest management systems that would suit the envisaged adjustment in planting date which is known to have significant effect on the incidence of pests and diseases $[22,27,28]$, considering that in the rainforest zone of Nigeria, grain legumes are preferably planted in the late season to take advantage of the approaching harmattan winds, 
rather than during the early season with its characteristic heavy rainfall which predisposes the crop to rot [29]. The legumes with an indeterminate growth pattern including African yam bean, Bebi bean, Bambara groundnut, and Mucuna bean in which maximum nodulation occurs about 2 months after sowing, should preferably be rotated with non-legume crops so that the subsequent crop benefits from the residual nitrogen fixed by them.

The effect of seed inoculation with Nodumax on nodule dry weight per plant varied with genotype and stage of plant growth at sampling, but was rather inconsistent over the sampling periods (Table 3). At the seedling stage, inoculation with Nodumax did not significantly affect the nodule dry weight of Bebi bean, African yam bean, Bambara groundnut, Mucuna bean and Cowpea, although it reduced that of Groundnut by 35\%. And whereas inoculation also did not significantly affect nodule dry weight of Bebi bean, Bambara groundnut, Mucuna bean and Cowpea when plants were sampled two weeks later, it increased the weight of African yam bean nodules by $60 \%$ while decreasing that of Groundnut by $75 \%$. Only the nodule dry weights of Bebi bean and Cowpea remained unaffected by inoculation with Nodumax when plants were sampled at the seed initiation stage. Those of African yam bean and Mucuna bean were increased by 56.5 and $60.6 \%$, respectively, while those of Bambara groundnut and Groundnut were respectively reduced by 25.6 and $50.0 \%$.

In terms of nodule dry weight therefore, inoculation of seed with Nodumax was neither beneficial nor harmful to Bebi bean, but was consistently harmful to Groundnut, reducing its weight by between 35 and $75 \%$. It is probable therefore, that Bebi bean is promiscuous and better adapted to the native/ indigenous strains of Rhizobium, while Groundnut is antagonistic and incompatible with the introduced inoculants.

\subsection{Production of Plant Biomass}

The African yam bean produced significantly more biomass than other test crops in both years of the study, followed by Bebi bean, Mucuna bean, Cowpea, Bambara groundnut and Groundnut (Table 4). Inoculating seeds with NoduMax was neither beneficial nor harmful to biomass production in African yam bean, Bebi bean and Bambara groundnut, but depressed that of Mucuna bean and Groundnut by $10.964 .4 \%$ (2015), and 12.4 and 52.5\% (2016). It however, increased the biomass produced by Cowpea by 17.9 and 16.6\% in 2015 and 2016, respectively.

\subsection{Carbon to Nitrogen Ratio (C: $N$ ) of Shoot}

The carbon to nitrogen ratio was not significantly affected by inoculation with Nodumax, but was rather a genotypic trait. The highest carbon to nitrogen ratio of 15: 1 was obtained with Groundnut shoots, followed by Bebi bean and Bambara groundnut (14:1), African yam bean (12:1), and Mucuna bean and Cowpea having the least ratio of 7:1 (Table 5). The C: N ratio which expresses the mass of carbon to that of nitrogen in a substance has significant effect on crop residue decomposition, particularly residue cover on the soil and nutrient recycling. A ratio of 30: 1 result in immobilization during the initial decomposition process; 20-30: 1 in neither immobilization nor release of mineral nitrogen, and <20: 1 in the release of mineral nitrogen early in the decomposition process [30]. Although all test crops had ratios less than the critical value of 20:1, the results indicate that when plant residue of either Mucuna bean and Cowpea is incorporated into the soil, it would decompose and mineralize about twice faster than that of either Groundnut, Bebi bean or African yam bean. Although plant genotypes differ in growth habit, morphological attributes and yield potential [31], there was significant Genotype $\times$ NoduMax inoculation interaction with respect to yield components and yield of the test crops (Table 6).

Inoculating Cowpea with NoduMax increased production of pods per plant from an average of 10.03 to 22.40, but reduced that of groundnut from 22.07 12.09. However, the number of pods produced by Bambara groundnut, Bebi bean, African yam bean and Mucuna bean was not significantly affected by treatment of seeds with NoduMax inoculant. The pods of Bebi bean contained significantly more seeds than that of other test crops, followed by African yam bean. Cowpea and Mucuna bean on the one hand and Bambara groundnut and groundnut on the other produced the same number of seeds per pod. Inoculating seeds with NoduMax inoculant resulted in significant Cowpea grain yield increase from an average of 2,471 to 2,794 kg/ ha and 2,995 to $3504 \mathrm{~kg} / \mathrm{ha}$ in 2015 and 2016. This was attributable to the positive effect of the inoculant on production of effective root nodules and higher dry root nodule weight, which might have resulted in a significant increase in biomass production. However, seed inoculation with NoduMax resulted in a significant reduction in Groundnut grain yield from 884 to $560 \mathrm{~kg} /$ ha and 963 to $678 \mathrm{~kg} / \mathrm{ha}$ in 2015 and 2016, respectively, while not affecting the yield of Bebi bean, African yam bean and Bambara groundnut.

\section{Conclusion}

Legumes are an invaluable source of plant protein and their residues can be used as fodder for livestock, and as mulch material and green manure for improving soil fertility.

Therefore, the inclusion of legumes in the cropping systems of resource-poor farmers of the rainforest zone of Nigeria can enhance livelihoods of the people. The response of legumes to inoculation with Nodumax varied with plant genotype, and while it was beneficial to Cowpea, it was harmful to groundnut probably because of incompatibility with the indigenous rhizobium. However, the African yam bean, Bebi bean, Bambara groundnut and Mucuna bean were better adapted to the native strains of Rhizobiumand were largely unaffected by inoculation with Nodumax. We suggest that given the wide variability in soil and weather of the area, a multi-location, on-farm evaluation of these genotypes should be conducted with NoduMax, and with other existing commercial inoculants before a recommendation is made 


\section{References}

i. Inaizumi H, Singh BB, Sanginga PC, Manyong VM, Adesina AA, Tarawali S. Adoption and impact of dry-season dualpurpose cowpea in the semiarid zone of Nigeria. Ibadan: International Institute of Tropical Agriculture (IITA); 1999.

ii. Quinn MA. Biological nitrogen fixation and soil health improvement. In: Erskins W, Muehlbauer, FJ, Sarker, A and Sharma, B editors. The Lentil Botany, Production and Uses; 2009.

iii. Mucheru-Muna M, Pypers P, Mugendi D, Kung'u J, Mugwe J, Merckx R, Vanlauwe B. Staggered maize-legume intercrop arrangement robustly increases crop yields and economic returns in the highlands of Central Kenya. Field Crops Res. 2010; 115:132-139.

iv. Giller KE. Nitrogen fixation in tropical cropping systems. 2nded. Guildford and King's Lynn: Biddles Ltd.; 2001.

v. Baudoin JP, Vanderborght T, Kimani PM, Mwang'ombe AW. Common bean (Phaseolus vulgaris L.). In: Raemaekers, $\mathrm{RH}$ editor. Crop production in tropical Africa Brussels: Directorate general for international co-operation, Ministry of Foreign Affairs, External Trade and International Co-operation; 2001

vi. Graham PH. Plant factors affecting symbiotic nitrogen fixation in legumes. In: Graham, PH and Harrris, SC editors. Biological nitrogen fixation: papers presented at a workshop held at Centro International de Agricultural Tropical (CIAT), 9-13 March, 1981, Cali, Colombia. 1982;27-37.

vii. Miller JC Jr., Scott JS, Zary KW, O'Hair SK. The influence of available nitrate levels on nitrogen fixation in three cultivars of cowpea. Agron J. 1982;74: 14-18. 8. Date RA. Inoculated legumes in cropping systems of the tropics. Field Crops Res. 2000;65(2-3):123-136.

viii. Vanlauwe B, Giller KE. Popular myths around soil fertility management in sub-Saharan Africa. Agric, Ecosyst and Env. 2006; 116:34-46.

ix. Ojo A, Dare MO, Fagbola O, Olubukola B. Variations in infectivity of indigenous rhizobial isolates of some soils in the rainforest zone of Nigeria. Archives Agron Soil Sci. 2015;61(3):371-380.

x. Bala A, Abaidoo R, Woomer P. Rhizobium strain isolation and characterization protocol; 2010. Available:www.N2Africa.org

xi. Bantilan MCS, Johansen C, Ladha JK, Peoples MB. Research evaluation and impact analysis of biological nitrogen fixation. Plant Soil. 1995; 174:279-286.

xii. N2Africa. N2Africa revitalizes legume production in Nigeria; 2015. (Accessed 2NdMarch 2017) Available:www.grainlegumes.cgiar.org/n2africa

xiii. Madukwe DK, Onuh MO, Christo IEC. Agronomic and physiological performance of Bambara groundnut (Vigna subterranean (L.) Verdc) in Southeastern Nigeria. World J. Agric Sci. 2011;7(2):166-173.

xiv. Summerfield RJ, Dart PJ, Huxley PA, Eaglesham ARJ, Minchin FR, Day JM. Nitrogen nutrition of cowpea (Vigna unguiculata). 1. Effects of applied nitrogen and symbiotic nitrogen fixation on growth and seed yield. Exptal Agric. 1977; 13:129-142.

xv. Amba AA, Agbo EB, Garba A. Effect of nitrogen and phosphorus fertilizers on nodulation of some selected grain legumes at Bauchi, Northern guinea savanna of Nigeria. Inter J Biosci. 2013;3(10):1-7.

xvi. Ibeawuchi II, Obiefuna JC, Nwufo MI, Ofoh MC. Nodulation and nitrogen fixation by landrace legumes in yam/ cassava based cropping systems of the tropical rainforest. New York Sci J. 2008;1(1):1-12.

xvii. Egbe MO, Alhassan GA, Ijoyah M. Nodulation, nitrogen yield and fixation by Bambara groundnut (Vigna subterranea(L.) Verdc.) landraces intercropped with cowpea and maize in southern guinea of Nigeria. Agric Sci. 2013;1(4):15-28.

xviii. Vanlauwe B, Mukalama J, Abaidoo RC, Sanginga N. Soybean varieties, developed in West Africa, retain their promiscuity and dual-purpose nature under highland conditions in western Kenya. In: A. Bationo, A, Waswa, B, Okeya, J Maina, MF and J. M. Kihara, JM editors. Innovations as key to the green revolution in Africa: Exploring the scientific facts. Netherlands: Springer; 2011.

xix. Aki EE, Esu IE, Akpan-Idiok AU. Pedological study of soils developed on Biotite-Hornblende-Gneiss in Akamkpa Local Government Area of Cross River State, Nigeria. Inter J Agric Res. 2014; 9(4):187-199.

xx. Binang WB, Ojikpong TO, Garjila YA, Esang DM, Okpara DA. Evaluation of liming materials and Bradyrhizobiuminoculation on the productivity of soya bean in the humid tropical ultisols of Southeastern Nigeria.J Agric and Sust. 2013;42(2):1-13.

xxi. IITA. Selected methods for soil and plant analysis. International Institute of Tropical Agriculture, IITA Monograph.1979;1:3-70.

xxii. Bala A, Abaidoo R, Woomer P. Rhizobium strain isolation and characterisation protocol; 2011. (Accessed 10 March 2017) Available:www.N2Africa.org

xxiii. Derr G, Everitt BS. A handbook of statistical analyses using SAS, 2ndedition. London: Chapman and Hall/ CRC; 2002.

xxiv. Oku E, Iwara A, Etukinam E. Effects of age of rubber (HeveabrasiliensisMuell Arg.) plantation on pH, organic carbon, organic matter, nitrogen and micronutrient status of ultisols in the humid forest zone. Kasetsart J. (Natural Science). 2012;46(5): 648-693.

xxv. Kahn BA, Stoffella PJ. Nodule distribution among root morphological components of field-grown cowpea. J Ame Soc Hort Sci. 1991;116(4):665-685.

xxvi. Ambe TT. The effect of planting dates on 3 cassava diseases in Cameroon. International J. Plant Mgt. 1993;39(3):309-311. 
xxvii. Makkouk KM, Kumari SG. Epidemiology and integrated management of persistently transmitted aphid-borne viruses of legume and cereal crops in West Asia and North Africa. Virus Res. 2009;141(2):209-218.

xxviii. Oko BFD, Solomon MG, Bakoh MY. A note on the effect of planting date and plant density on the productivity of soybean in a humid tropical environment. Trop J Appl Sci. 1991; 1:38-41.

xxix. USDA. Carbon to nitrogen ratios in cropping systems. USDA Natural Resources Conservation Service; 2011. Available:www.soils.usda.gov/ sqi (Assessed on 28/ 02/ 17)

xxx. Egbutah EU, Obasi MO. Productivity, nitrogen fixation and grain yield of legumes intercropped with roselle in southern and northern guinea savannah of Nigeria. Cont J Agric Sci. 2016;10(2):1-14

\section{Appendix}

\begin{tabular}{|c|c|c|c|c|}
\hline Treatment & \multicolumn{3}{|c|}{ Weeks after Sowing } & Mean \\
\hline & 4 & 6 & 8 & \\
\hline Inoculated & & & $26.0 \mathrm{ab}$ & 22.77 \\
Bebi beans & $20.0 \mathrm{ab}$ & $22.3 \mathrm{~b}$ & $24.3 \mathrm{~b}$ & 21.0 \\
African yam beans & $18.7 \mathrm{~b}$ & $20.0 \mathrm{bc}$ & $29.2 \mathrm{a}$ & 25.53 \\
Bambara groundnut & $22.7 \mathrm{a}$ & $24.7 \mathrm{a}$ & $26.0 \mathrm{ab}$ & 19.33 \\
Mucuna & $13.3 \mathrm{c}$ & $19.0 \mathrm{c}$ & $13.0 \mathrm{~d}$ & 19.13 \\
Groundnut & $12.0 \mathrm{c}$ & $13.7 \mathrm{~d}$ & $18.7 \mathrm{c}$ & \\
Cowpea & $18.0 \mathrm{~b}$ & $20.7 \mathrm{bc}$ & & 24.43 \\
Non-inoculated & & & $27.2 \mathrm{ab}$ & 24.70 \\
Bebi beans & $23.0 \mathrm{a}$ & $23.1 \mathrm{ab}$ & $28.6 \mathrm{~b}$ & 24.17 \\
African yam beans & $23.3 \mathrm{a}$ & $25.2 \mathrm{a}$ & $24.8 \mathrm{~b}$ & 13.33 \\
Bambara groundnut & $22.2 \mathrm{a}$ & $26.7 \mathrm{a}$ & $13.1 \mathrm{~d}$ & \\
Mucuna & $23.2 \mathrm{a}$ & $24.5 \mathrm{a}$ & $13.8 \mathrm{~d}$ & \\
Groundnut & $12.3 \mathrm{c}$ & $14.6 \mathrm{~d}$ & & \\
Cowpea & $13.0 \mathrm{c}$ & $15.7 \mathrm{~d}$ & & \\
& & & & \\
\hline
\end{tabular}

Table 2: Interaction Effect of Genotype and Inoculation on Number of Effective Root Nodulesper Plant

In a column means followed by the same letter are not significantly different at 5\% probability levels according to DNMRT

\begin{tabular}{|c|c|c|c|c|}
\hline Treatment & \multicolumn{3}{|c|}{ Weeks after Sowing } & Mean \\
\hline & $\mathbf{4}$ & $\mathbf{6}$ & $\mathbf{8}$ & \\
\hline Inoculated & $2.3 \mathrm{~b}$ & $2.0 \mathrm{c}$ & $2.0 \mathrm{c}$ & 2.10 \\
Bebi beans & $1.7 \mathrm{bc}$ & $2.0 \mathrm{c}$ & $2.3 \mathrm{c}$ & 2.0 \\
African yam beans & $3.7 \mathrm{a}$ & $3.0 \mathrm{~b}$ & $3.2 \mathrm{~b}$ & 3.30 \\
Bambara groundnut & $2.3 \mathrm{~b}$ & $3.3 \mathrm{~b}$ & $3.3 \mathrm{~b}$ & 2.97 \\
Mucuna & $1.3 \mathrm{c}$ & $1.0 \mathrm{~d}$ & $1.0 \mathrm{~d}$ & 1.10 \\
Groundnut & $1.3 \mathrm{c}$ & $3.0 \mathrm{~b}$ & $2.3 \mathrm{c}$ & \\
Cowpea & & & $2.0 \mathrm{c}$ & 1.93 \\
Non-inoculated & $2.0 \mathrm{~b}$ & $1.8 \mathrm{c}$ & $1.0 \mathrm{~d}$ & 3.20 \\
Bebi beans & $1.8 \mathrm{bc}$ & $0.8 \mathrm{~d}$ & $4.3 \mathrm{a}$ & 1.97 \\
African yam beans & $4.4 \mathrm{a}$ & $2.5 \mathrm{~b}$ & $1.3 \mathrm{~d}$ & 2.67 \\
Bambara groundnut & $1.7 \mathrm{bc}$ & $2.9 \mathrm{~b}$ & $2.0 \mathrm{c}$ & 1.50 \\
Mucuna & $2.0 \mathrm{~b}$ & $4.0 \mathrm{a}$ & $1.5 \mathrm{~d}$ & \\
Groundnut & $1.8 \mathrm{bc}$ & $1.2 \mathrm{~d}$ & & \\
Cowpea &
\end{tabular}

Table 3: Interaction Effect of Genotype and Inoculation on Nodule Dry Weight per Plant (G) Treatment

In a column means followed by the same letter are not significantly different at 5\% probability levels according to DNMRT 


\begin{tabular}{|c|c|c|}
\hline Treatment & \multicolumn{2}{|c|}{ Fresh Biomass (kg/ ha) } \\
\hline & 2015 & 2016 \\
\hline Inoculated & $5,002.22 \mathrm{de}$ & $6,380.25 \mathrm{~d}$ \\
Bambara groundnut & $8,013.58 \mathrm{~b}$ & $8,066.67 \mathrm{~b}$ \\
Bebi bean & $9,128.32 \mathrm{a}$ & $10,654.32 \mathrm{a}$ \\
African yam bean & $7,135.87 \mathrm{c}$ & $7,103.70 \mathrm{c}$ \\
Mucuna bean & $1,511.14 \mathrm{f}$ & $2,091.36 \mathrm{f}$ \\
Groundnut & $6,901.27 \mathrm{c}$ & $7,098.77 \mathrm{c}$ \\
Cowpea & & $6,279.04 \mathrm{~d}$ \\
Non-inoculated & $5,770.23 \mathrm{~d}$ & $8,115.04 \mathrm{~b}$ \\
Bambara groundnut & $8,040.66 \mathrm{~b}$ & $8,983.49 \mathrm{ab}$ \\
Bebi bean & $8,860.11 \mathrm{ab}$ & $8,105.97 \mathrm{~b}$ \\
African yam bean & $8,006.82 \mathrm{~b}$ & $4,401.37 \mathrm{e}$ \\
Mucuna bean & $4,249.21 \mathrm{e}$ & $5,919.62$ \\
Groundnut & $5,663.90 \mathrm{~d}$ & \\
\hline
\end{tabular}

Table 4: Interaction Effect of Genotype and Inoculation on Fresh Biomass Weight in 2015 and 2016 Cropping Seasons

\begin{tabular}{|c|c|c|c|}
\hline Legume Species & \% & \% & C:N \\
\hline & Nitrogen & Carbon & $14: 1$ \\
Bebi bean & 4.2 & 60.44 & $12: 1$ \\
African yam bean & 3.36 & 41.09 & $14: 1$ \\
Bambara groundnut & 3.36 & 47.48 & $7: 1$ \\
Mucuna bean & 5.36 & 41.28 & $15: 1$ \\
Groundnut & 3.64 & 55.46 & $7: 1$ \\
Cowpea & 5.40 & 40.55 & \\
\hline
\end{tabular}

Table 5: Carbon (C) to Nitrogen (N) Ratio of Shoots of Grain Legumes Grown at Akamkpa

\begin{tabular}{|c|c|c|c|c|c|c|c|c|}
\hline Treatment & 2015 & & & & 2016 & & & \\
\hline & $\begin{array}{c}\text { No of } \\
\text { Pods/ plant }\end{array}$ & $\begin{array}{c}\text { No of } \\
\text { Seeds/ pod }\end{array}$ & $\begin{array}{c}100 \text { seed } \\
\text { Weight } \\
(\mathrm{g})\end{array}$ & $\begin{array}{c}\text { Grain } \\
\text { yield } \\
\text { (kg/ha) }\end{array}$ & $\begin{array}{c}\text { No of } \\
\text { Pods/ plant }\end{array}$ & $\begin{array}{c}\text { No of } \\
\text { Seeds/ pod }\end{array}$ & $\begin{array}{c}100 \text { seed } \\
\text { Weight } \\
(\mathrm{g})\end{array}$ & $\begin{array}{c}\text { Grain } \\
\text { yield } \\
\text { (Kg/ ha) }\end{array}$ \\
\hline \multicolumn{9}{|l|}{ Inoculated } \\
\hline Bebi bean & $32.0 \mathrm{~b}$ & $22.3 \mathrm{a}$ & $10.6 \mathrm{a}$ & $921 \mathrm{e}$ & 33.0ab & $23.5 \mathrm{a}$ & $11.0 \mathrm{c}$ & $1,032 \mathrm{e}$ \\
\hline $\begin{array}{c}\text { African } \\
\text { Yam bean }\end{array}$ & $24.05 \mathrm{c}$ & $20.70 \mathrm{~b}$ & $30.07 \mathrm{~b}$ & $1,576 \mathrm{c}$ & $26.14 \mathrm{~b}$ & $20.10 \mathrm{~b}$ & $31.04 \mathrm{~b}$ & $2,766 \mathrm{c}$ \\
\hline $\begin{array}{l}\text { Bambara } \\
\text { groundnut }\end{array}$ & $39.10 \mathrm{a}$ & $1.08 \mathrm{a}$ & $51.90 \mathrm{a}$ & $1,256 a$ & $35.13 a$ & $1.10 \mathrm{a}$ & 54.84 & $1,331 d$ \\
\hline Cowpea & $22.40 \mathrm{c}$ & $14.02 \mathrm{c}$ & $23.6 \mathrm{c}$ & $2,794 a$ & $15.30 \mathrm{c}$ & $13.30 \mathrm{c}$ & $15.46 c$ & $3,504 a$ \\
\hline Groundnut & $12,09 \mathrm{c}$ & $2.40 \mathrm{c}$ & 10.90c & 560 & 13.04 & $2.06 \mathrm{~d}$ & $11.04 \mathrm{c}$ & 678 \\
\hline $\begin{array}{l}\text { Mucuna } \\
\text { bean }\end{array}$ & $20.50 \mathrm{c}$ & $13.01 \mathrm{c}$ & $13.77 \mathrm{c}$ & 1696b & $22.11 \mathrm{c}$ & $13.50 \mathrm{c}$ & $15.43 c$ & 1,467 \\
\hline \multicolumn{9}{|c|}{ Non-Inoculated } \\
\hline Bebi bean & $31.05 \mathrm{~b}$ & $22.0 \mathrm{a}$ & $10.03 d$ & $842 \mathrm{c}$ & $32.30 \mathrm{ab}$ & $23.70 \mathrm{a}$ & $10.98 \mathrm{a}$ & $998 \mathrm{c}$ \\
\hline $\begin{array}{c}\text { African } \\
\text { yam bean }\end{array}$ & $23.01 \mathrm{c}$ & $18.0 \mathrm{~b}$ & $30.60 \mathrm{~b}$ & $1,564 \mathrm{c}$ & $23.10 \mathrm{bc}$ & $18.30 \mathrm{~b}$ & $30.82 \mathrm{~b}$ & $2,519 \mathrm{c}$ \\
\hline $\begin{array}{l}\text { Bambara } \\
\text { groundnut }\end{array}$ & $37.00 \mathrm{a}$ & $1.04 \mathrm{c}$ & $53.30 \mathrm{a}$ & $1,237 \mathrm{c}$ & $38.20 \mathrm{a}$ & $1.50 \mathrm{c}$ & $53.17 a$ & $1,266 \mathrm{c}$ \\
\hline Cowpea & $10.03 \mathrm{c}$ & $13.10 \mathrm{c}$ & $23.27 \mathrm{c}$ & $2,471 b$ & $12.90 \mathrm{a}$ & $13.05 \mathrm{c}$ & $13.33 \mathrm{~cd}$ & $2,995 \mathrm{~b}$ \\
\hline Groundnut & $22.07 \mathrm{~cd}$ & $2.06 \mathrm{~d}$ & 19.80b & $884 \mathrm{c}$ & $23.0 \mathrm{bc}$ & $2.20 \mathrm{c}$ & $11.12 \mathrm{c}$ & $963 \mathrm{c}$ \\
\hline $\begin{array}{l}\text { Mucuna } \\
\text { bean }\end{array}$ & $20.90 \mathrm{c}$ & $13.00 \mathrm{c}$ & 13.11c & $2,525 b$ & $18.6 \mathrm{c}$ & $13.08 \mathrm{c}$ & $13.07 \mathrm{bc}$ & $2,853 \mathrm{~b}$ \\
\hline
\end{tabular}

Table 6: Yield Components and Fresh Grain Yield of Inoculated and Non-Inoculated Legumes Grown in Akamkpa in 2015 and 2016 Late Cropping Seasons

In a column means followed by the same letter are not significantly different at 5\% probability levels according to DNMRT 